\title{
EGYETEMI HALLGATÓK AKTÍV SPORTFOGYASZTÁSI SZOKÁSAINAK VIZSGÁLATA
}

\author{
Szerdahelyi Zoltán
}

\section{Összefoglalás}

A Debreceni Egyetem hallgatóinak aktiv sportfogyasztási szokásainak vizsgálatát több szempontból is hasznosnak tartom. Ezen terület feltérképezésével hatékonyabbá válhatnak a fizikai aktivitás növelését célzó intézkedések, igy a kinálati oldal összetevöinek meghatározása. A Gyermeknevelési és Gyógypedagógiai Kar speciális helyzetben van a többi karhoz képest. A hajdúböszörményi telephely és a hallgatók szociokulturális háttere egyaránt indokolttá teszi a helyi sajátosságok figyelembe vételét.

Kérdöives kutatást alkalmaztam $(N=338)$. Elemeztem, hogy a hallgatók fizikai aktivitását a különbözö szociodemográfiai, kulturális és ökonómiai tényezők milyen mértékben befolyásolják. Elmondhatom, hogy a jövedelemtényezö a rangsor közepén foglal helyet. A jövedelmi viszonyokra jellemzöek a hallgatók közti nagy különbségek. A hallgatókat alacsony ráforditási hajlandóság jellemzi a fizikai aktivitással összefüggésben. Az iskolai végzettség és a sporttevékenységekhez kapcsolódó havi kiadások között nem találtam szignifikáns kapcsolatot. A kutatás során vizsgáltam, hogy milyen jellegü sporttevékenységért hajlandók fizetni a hallgatók. Elökelo" helyet foglal el a túrázás, illetve a "divatos edzésmódszerekként" aposztrofált tevékenységek (aerobik, zumba, spinning, jumping fitness, nordic walking, crossfit, jóga). A havonta megszerzett jövedelem és a sportfogyasztás közti kapcsolatot elemezve két esetben tapasztaltam szignifikáns összefüggést: a konditerem és a „divatos edzésmódszerek” bérleteinek vásárlása során.

Kulcsszavak: sportfogyasztás, fogyasztói magatartás, fizikai aktivitás, szabadidösport, egyetemi hallgatók

JEL: D19 


\title{
EXAMINATION OF THE ACTIVE SPORTS CONSUMPTION HABITS OF STUDENTS OF THE UNIVERSITY OF DEBRECEN
}

\begin{abstract}
I consider the examination of the active sports consumption habits of students of the University of Debrecen to be useful in several respects. By mapping this area, measures to increase physical activity, such as the definition of facility side components, can be more effective. The Faculty of Child and Special Needs Education is in a special position compared to other faculties. Both the Hajduiböszörmény site and the sociocultural background of the students justify taking local specificities into consideration.

I used a questionnaire research $(N=338)$. In addition to socio-demographic data, the questions examined costs of leisure and leisure activities

I have analysed the extent to which students' physical activity is affected by various sociodemographic, cultural and eco-factors. I can tell you that the income factor sits in the middle of the rankings. The income conditions are characterised by large differences between students. Students show a low inclination to invest in connection with physical activity. There was no significant link between academic achievement and the monthly costs related to sports activities. In the course of the research, I examined the types of sports activities students are willing to pay for. Hiking and exercising considered as "trendy exercising" (aerobics, zumba, spinning, jumping fitness, Nordic walking, crossfit, yoga) are high on the list. By analysing the relationship between monthly income and sports consumption, I found a significant correlation in two cases: buying season tickets for gym and "trendy exercising".
\end{abstract}

Keywords: sports consumption, consumer behaviour, physical activity, leisure sports, university students

JEL: D19 


\section{Bevezetés}

Világszerte egyre nagyobb hangsúlyt kap az egészséges életmód, amelynek keretében kiemelt figyelmet szentelnek a sportra és fizikai tevékenységekre fordított idő növelésére (Bácsné et al., 2018a). A mozgás az emberi élet egyik meghatározó alapköve. A mindennapi cselekvéseink sikeres végrehajtásán kívül meghatározó szerepe van a testi-lelki-szellemi egészség megőrzésében (Laczkó-Rétsági, 2015; Dajnoki et. al, 2018), helyreállításában és javításában, illetve a gyermekben és felnőttben egyaránt jelen lévő játékigény (Laczkó-Melczer, 2015) kielégítésében.

Napjaink aktív sportszolgáltatói piaca dinamikus bővülést mutat mind vertikális (egyre több mozgásforma), mind horizontális (egyre több/professzionálisabb szolgáltató) szempontból (Laczkó-Melczer, 2015; Bácsné et al., 2018b). Az egyén társadalmi nemétől (Bácsné et al., 2019a; Fenyves et al., 2019; Madarász et al., 2019;), lakhelyétől, jövedelmi viszonyától, illetve a belső és külső motiváló tényezők erősségétől függően fogyaszt a rendelkezésre álló javakból (Ács, 2015). Egyre több tudományos munka (Kovács et al., 2015; Bácsné et al., 2018c) foglalkozik a sportkiadások számszerűsítésével, számos tényező hatását (jövedelem, lakhely, iskolai végzettség) azonosítva (Pfau, 2016a; Pfau, 2016b; Bácsné et al., 2018d; Bácsné et al., 2019b; Gabnai et al., 2019).

A fogyasztó dönt, hogy mennyit és milyen gyakran hajlandó költeni az aktív sportfogyasztásra. A ráfordítási hajlandóságnak több szegmensét különböztethetjük meg. Egyrészt a rendelkezésünkre álló szabadidő mennyiségével való gazdálkodás, másrészt a fizikai aktivitásra vonatkozó energiabefektetés és a rendelkezésre álló jövedelemből történő ráfordítás oldaláról is vizsgálhatjuk a kérdést. A négyévente elvégzett európai uniós kutatásokból (Eurobarometer on Sport and Physical Activity, 2014) az is kiderül, hogy a mozgásos inaktivitást az érintettek 11 százaléka hozta összefüggésbe a magas ráfordítási költségekkel.

Annak érdekében, hogy a hallgató meg tudja vásárolni az adott szolgáltatást, rendelkeznie kell az ehhez szükséges jövedelemmel. A nappali tagozatos hallgatók több alternatíván keresztül juthatnak ehhez a jövedelemhez. Az egyik alternatíva a támogató családi háttér, a másik a tanulmányi és szociális ösztöndíj, a harmadik a Diákhitel (Szabó, 2015). A munkavállalás (Ács, 2015), mellyel döntési kényszerbe kerül az egyén (duális döntési helyzet), szükségszerüen csökkenti a sportolásra (is) fordítható szabadidő mennyiségét. A vonatkozó szakirodalom (Paár, 2013) fontos kiegészítő kérdésekkel árnyalja a döntéshozatalt befolyásoló tényezőket. Milyen gyakran vásárolok (napijegy, havi/éves bérlet)? Mennyi időt tudok „,befektetni” a szabadidőmből (30perces úszás, 60 perces spinningedzés, 120 perces konditermi edzés)? A levelező tagozatos hallgatók esetében a munkavállalásból származó jövedelmet tekintem elsődlegesnek. Pawlowski (2009) kétdimenziós modelljét felhasználva helyezte el Ács (2015) az egyetemistákat a rendelkezésre áló szabadidő és jövedelem függvényében. 
Ebben az esetben is különbséget kell feltételeznünk a nappali és a levelező tagozatos hallgatók pozíciója között. Míg a nappali munkaformában tanulók vélhetően több szabadidővel, de kevesebb jövedelemmel rendelkeznek, addig a levelezősök több jövedelemmel, de kevesebb szabadidővel rendelkeznek, mely tényezők alapvetően befolyásolhatják (Fritz et al., 2007) a fizikai aktivitás növelésére tett hallgatói erőfeszítéseket.

Kutatásom során a jövedelemráfordítás tényezőjével kapcsolatos kérdéseket fogalmaztam meg. A hallgató mennyi jövedelemmel rendelkezik, és ennek mekkora hányadát hajlandó a fizikai aktivitás növelésére fordítani? Milyen kapcsolat áll fenn a sporttevékenység időbeli jellemzői és a hallgatói sportfogyasztás kiadásai között? Egyszeri ráfordítás szükséges, vagy periodikusan jelentkező költségekről beszélhetünk? Milyen költségei vannak ezeknek a tevékenységeknek? A hallgató folyamatosan hajlandó ráfordításokat eszközölni, például a szabadidősport-tevékenység folytatására vagy alkalomszerủen? Ez utóbbi kérdés azért is kulcsfontosságú, mert a fizikai aktivitás csak abban az esetben fejti ki pozitív hatásait, ha az a mindennapi életünk szerves részévé válik. Ez pedig feltételezi a rendszerességet, az anyagi javak bizonyos hányadának „befektetése” terén is.

\section{Anyag és módszer}

A kutatást a Debreceni Egyetem Gyermeknevelési és Gyógypedagógiai Karának hallgatói körében végeztem el 2019 szeptemberében. A Gyermeknevelési és Gyógypedagógiai Kar hallgatói számára kettő lehetőség a meghatározó, a karunkon történő rendszeres testmozgással összefüggésben: a tantervi testnevelés órák, illetve a hallgatói szabadidősport-tevékenységek. Utóbbira jellemző az önszerveződés hiánya. Ebből fakad, hogy ez a terület is kizárólag az oktatók munkaidőn túl szervezett szabadidősport-foglalkozásaira korlátozódik a karon, bár a hallgatói érdekérvényesítés különböző formái lehetőséget adnának változatosabb sportélet kialakítására.

Campusunk infrastrukturális ellátottságát vizsgálva megállapítható, hogy a hajdúböszörményi kari telephely egy tornateremmel és egy szabadtéri sportpályával rendelkezik (egy aszfaltburkolatú kosárlabdapálya, illetve egy salakpálya). Gyakorlati tapasztalataim szerint ilyen feltételek mellett még nehezebb a napjainkra jellemző, élményközpontúságot a középpontba helyező hallgatói attitüdöknek/elvárásoknak megfelelő kínálatot biztosítani, az alacsonyabb egyéni (habituális) motivációs szint mellett.

A mintám reprezentatív nemre és a munkaformára (nappali/levelező) nézve. A kar hallgatóinak 95\%-a nő és csupán 5\%-a férfi. A vizsgált minta hasonló arányokat mutat. Ebben az esetben tehát nem releváns a nemek közti különbségeket vizsgálni, 
és a válaszadók társadalmi nemi hovatartozása alapján kijelenthető, hogy a női hallgatókra vonatkoztathatóak az eredmények. Természetesen nem általánosíthatunk a kutatási eredmények alapján, hiszen a sportfogyasztási szokásokat a nemen kívül egyéb tényezők is befolyásolhatják (jövedelem, lakhely, életkor).

A 28 itemből álló online kérdőívet 338 fö töltötte ki $(\mathrm{N}=338)$. A kérdőív 28 itemből áll, melynek összeállításakor felhasználtam nemzetközileg validált kérdőíveket (IPAQ - International Physical Activity Questionnaire, PALMS - Physical Activity and Leisure Motivation Scale, EQ-5D - EuroQoL skála - European Quality of Life, SF-36 - 36 item Short Form Health Survey), valamint saját szerkesztésü kérdéseket. A kérdések a szociodemográfiai adatokon (nem, kor, lakhely, jövedelmi viszonyok) túl vizsgálják a szabadidősportra fordított/fordítandó kiadásokat.

A kérdések között megtalálhatóak a nyílt végü, illetve zárt végű kérdések egyaránt. Több kérdés esetében ötfokozatú Likert-skálán adhaták meg a válaszadóra jellemző értékeket.

A kérdőívet Google Ürlap segítségével készítettem el. A kitöltött kérdőívek adatait statisztikai elemzőprogram (SPSS Statistics 25.0) segítségével rendszereztem, és végeztem el a leíró statisztikai elemzésen kívül a szükséges próbákat (kereszttábla-elemzés, khi-négyzet-próba).

\section{Eredmények}

A férfi és női válaszadók aránya hasonló a teljes populáció nemenkénti megoszlásához. A hallgatók 95,1 százaléka nő, 4,9 százaléka férfi. A kérdőívet kitöltők 94,7 százaléka nő, és csupán 5,3 százaléka férfi.

A kérdőívet kitöltők 25,4 százaléka falun, 51,2 százaléka városban, 21,6 százaléka megyeszékhelyen és 1,8 százaléka a fóvárosban él.

A vizsgált populáció oktatási rendszerben elfoglalt helye miatt (egyetemi képzés), az iskolai végzettség kérdésre három lehetséges választ adhattak a megkérdezettek (érettségi, diploma, posztgraduális). A válaszok alapján az is nyilvánvalóvá vált, hogy a levelező tagozatos hallgatók nagyobb arányban válaszoltak a kérdőív kérdéseire (58,6 százalék).

Kíváncsi voltam, hogy a hallgatók fizikai aktivitását a különböző szociodemográfiai, kulturális és ökonómiai tényezők milyen mértékben befolyásolják (1. táblázat).

A válaszokból arra a következtetésre jutottam, hogy leginkább az otthoni környezet megőrzése és fejlesztése, a szabadidő mennyisége és természetesen az egészségi állapot van a legnagyobb hatással a mozgásos tevékenységekre. Fontos objektív szempont lehet még a lakhely infrastrukturális ellátottsága, illetve a szubjektív kategóriának tekinthető baráti környezet hatásai is. 
A jövedelemtényező a rangsor közepén foglal helyet, tehát ezt nem tekinthetjük meghatározó faktornak a hallgatói vélemény szerint. Ez az eredmény egybevág a jövedelem és az aktív sportfogyasztás kiadásainak összefüggéseivel kapcsolatos eredményekkel.

A rangsor alján olyan tényezőket találunk, melyektől előkelőbb helyezést vártam előzetesen. Az ismeretterjesztő médiumok naponta közvetítik a lakosság felé az inaktivitás negatív következményeit, de mégsem rendelkeznek a megfelelő motiváló erővel. Ebből az is következik, hogy nem információhiány, hanem a habituális motiváció gyengesége jellemzi a vizsgált minta tagjait. A legkisebb befolyásoló erővel a közoktatáshoz kapcsolódó testnevelésórák bírnak. Nincs jelentős különbség az általános iskolai és a középiskolai testnevelés hatása között. Az egyik lehetséges magyarázat a hagyományos, teljesítménycentrikus testnevelés közelmúltig tartó egyeduralmának negatív hatása. A diákok élmény- és örömszerző tevékenysége háttérbe szorult, a rögzített sztenderdek alapján, érdemjeggyel történő értékelés mellett.

A jövedelmi viszonyokat tekintve megállapítható, hogy a hallgatók között nagy különbségek vannak a havi nettó keresetük vonatkozásában (100 000 forint alatt és 500000 forint fölött). 2019 augusztusában a havi nettó átlagkereset 240000 forint körüli értéket mutatott. Ezt az adatot összevetve a mintához tartozó értékekkel, megállapítható, hogy a hallgatók 91,7 százaléka a magyar átlagbérnek megfelelő (vagy annál kisebb) összeghez jut hozzá havonta. Ennek magyarázata kétirányú. Egyrészt kisebb jövedelemmel rendelkeznek a nappali tagozatos hallgatók, másrészt a levelező hallgatók jelentős része állami alkalmazott (pl. közalkalmazott), így fizetésük nem tart lépést a versenyszféra bérezésével. Karunkra jellemző a hátrányos helyzetü hallgatók magas aránya, mely szintén az alacsonyabb jövedelem megszerzését valószínűsíti.

$\mathrm{Az}$ 1. ábra a sporttevékenységekre fordított havi átlagkiadásokat tartalmazza. Szembetűnő, hogy a legalacsonyabb összeget költők csoportja adja az összes válaszadó 64,5 százalékát, illetve a három legkisebb ráfordítással rendelkező kategóriához tartozik a megkérdezettek 96 százaléka. A diagram adatainak elemzése igazolja azt a feltételezésem, hogy a hallgatókat alacsony ráfordítási hajlandóság jellemzi, a mozgásos tevékenységekkel összefüggésben. 


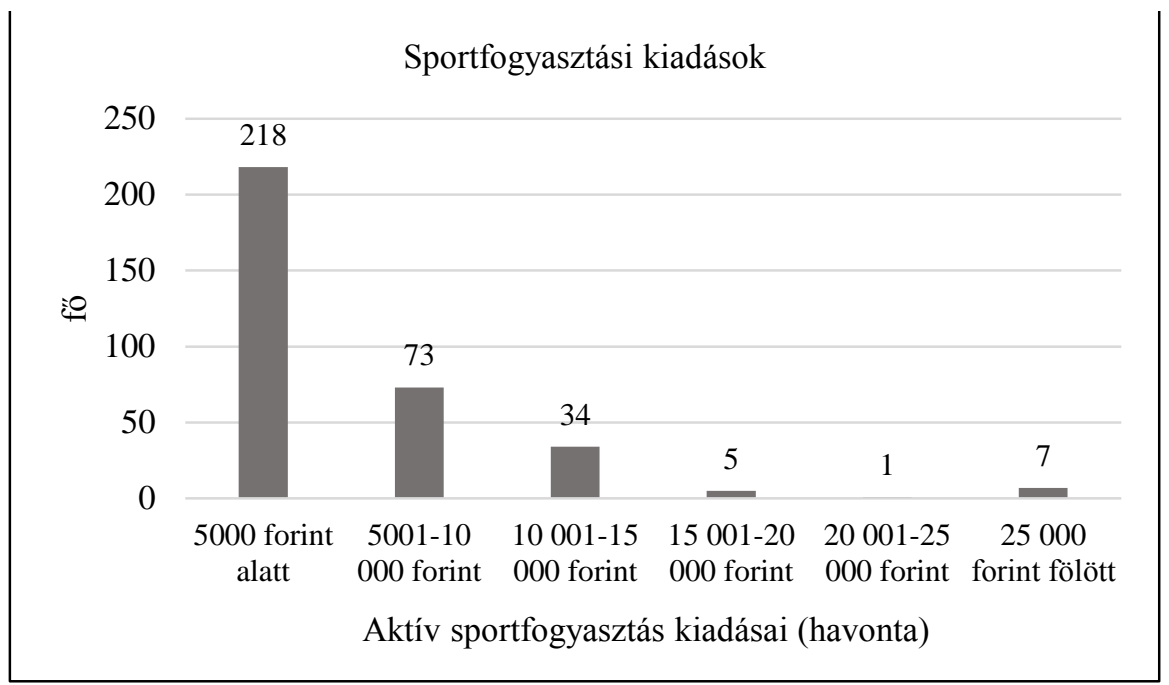

1. ábra: Egyetemi hallgatók aktív sportfogyasztással kapcsolatos kiadásai Forrás: saját szerkesztés

$\mathrm{Az}$ iskolai végzettség és a sporttevékenységekhez kapcsolódó havi kiadások között nincs szignifikáns kapcsolat. Annak ellenére, hogy a diplomával rendelkező (levelezö) hallgatók és a „csak” érettségivel rendelkezo (nappalis) hallgatók jövedelmi viszonyai között szignifikáns eltérés tapasztalható, az előbbi csoport tagjai nem mutatnak nagyobb hajlandóságot a sporttevékenységekbe való befektetésbe.

Ennek lehetséges magyarázata a szabadidővel való gazdálkodás és a duális döntési helyzet kérdéséhez vezet. A levelező hallgató ugyan magasabb jövedelemmel rendelkezik, de tanulmányi kötelezettsége mellett el kell látnia a munkahelyi feladatait, illetve a családi kötelezettségekhez kapcsolódó feladatokat is. Utóbbi, a nők hangsúlyosabb jelenléte miatt hatványozottan érvényesülhet.

A kutatás során azt is vizsgáltam (1. táblázat), hogy milyen jellegü sporttevékenységért hajlandók fizetni a hallgatók. A kérdőív kérdései az időtényezőt is figyelembe vették, azaz kitértek arra a fontos fogyasztói döntésre, hogy inkább alkalomszerủen vesznek igénybe sportszolgáltatásokat (napijegy) vagy rendszeresen (bérlet). Ezt azért is tartom fontosnak, mert a bérletvásárlás hosszú távú gondolkodást feltételez a fogyasztó részéről, azaz az egyén stratégiát alkot a fizikai-szellemi-lelki állapotának magasabb szintre emeléséről. Az ilyen jellegü befektetések egészségügyi, gazdasági és társadalmi haszna tagadhatatlan. 
1. táblázat: A mozgásformákkal kapcsolatos ráfordítási hajlandóság

\begin{tabular}{|l|c|c|c|}
\hline \multicolumn{1}{|c|}{ mozgásforma } & $\begin{array}{c}\text { érték } \\
\text { (1-től 5-ig } \\
\text { terjedő } \\
\text { skálán) }\end{array}$ & szórás & $\begin{array}{c}\text { rangsor- } \\
\text { ban elfog- } \\
\text { lalt hely }\end{array}$ \\
\hline túrázás (aerobik, & 2,66 & 1,40 & 1. \\
\hline $\begin{array}{l}\text { „divatos edzésmódszerek” zumba, jumping fitness, crossfit, spinning, } \\
\text { jóga, nordic walking...) -napijegy }\end{array}$ & 1,89 & 1,26 & 2. \\
\hline $\begin{array}{l}\text { „divatos edzésmódszerek” (aerobik, } \\
\text { zumba, jumping fitness, crossfit, spinning, } \\
\text { jóga, nordic walking...) -bérlet }\end{array}$ & 1,71 & 1,17 & 3. \\
\hline uszoda - napijegy & 1,64 & 1,04 & 4. \\
\hline konditerem - bérlet & 1,55 & 1,13 & 5. \\
\hline $\begin{array}{l}\text { csapatsport - terembérleti díj, egyesületi } \\
\text { tagság }\end{array}$ & 1,42 & 0,98 & 6. \\
\hline $\begin{array}{l}\text { extrém sportok (sziklamászás, hegyi kerék- } \\
\text { pározás, ejtőernyőzés, szörfözés, búvárko- } \\
\text { dás...) }\end{array}$ & 1,35 & 0,89 & 7. \\
\hline uszoda - bérlet & 1,32 & 0,87 & 8. \\
\hline konditerem - napijegy & 1,30 & 0,72 & 9. \\
\hline
\end{tabular}

Forrás: saját szerkesztés

A megkérdezettek preferenciaskálájának alján olyan mozgásformák (súlyzós erősítés, úszás, extrém sportok, csapatsportok) találhatóak, melyek férfias jellegének megítélése napjainkban is szilárdan tartja magát (Bujdosó-Dávid, 2013). Az egyetemi kar nemi jellemzőit figyelembe véve érthető, hogy ezekre a mozgásformákra keveset hajlandóak költeni a hallgatók. A skálán előkelő helyet foglal el a túrázás, illetve a „divatos edzésmódszerekként" aposztrofált tevékenységek (aerobik, zumba, spinning, jumping fitness, nordic walking, crossfit, jóga). A legmagasabb érték a túrázás esetében jelenik meg. A kérdőív egy másik kérdéséből az is kiderült, hogy a hallgatók negyede nem hajlandó költeni a sportfelszerelésre, míg háromnegyed részük kisebb/nagyobb mértékben igen.

Feltételeztem, hogy a sportfelszerelésre és a túrázásra történő költés között statisztikailag is kimutatható kapcsolat áll fenn, ezért ezt a két tényezőt kereszttáblaelemzéssel vizsgáltam, és khi-négyzet-próbát végeztem. Mivel $\mathrm{p}<0,05$, ezért a gamma értéket $(0,612)$ is figyelembe vettem a kapcsolat erősségének megállapításakor. Az összes mozgásformát figyelembe véve a fenti két tényező (túrázás - sportfelszerelés) között áll fenn a legerősebb kapcsolat (4. diagram), mely 
pozitív irányú. A túrázás költségei alapvetően az útiköltséghez és a szükséges felszereléshez kapcsolódnak. A részvétel költségei csak túravezető által szervezett alkalmakkor jelentkezhetnek.

A különböző jövedelmi kategóriákba sorolható hallgatók ráfordítási hajlandóságát is vizsgáltam, kategóriánként összehasonlítva a különböző mozgásos tevékenységekkel. Azt szerettem volna megtudni, hogy van-e összefüggés a havonta megszerzett jövedelem és az egyes mozgásos tevékenységekhez kapcsolódó sportfogyasztás között. Szignifikáns kapcsolatot kettő esetben tapasztaltam: a konditerem és a „divatos edzésmódszerek” bérleteinek vásárlása során. A kapcsolat nem erős, és negatív irányú. Ez azt jelenti, hogy az alacsonyabb havi jövedelemmel rendelkezőkre inkább jellemző a bérletek vásárlása, amely bizonyos fokú vásárlói tudatosságot feltételez.

\section{Következtetések, javaslatok}

A vizsgálat eredménye szerint nincs szignifikáns kapcsolat a jövedelem nagysága és a sporttevékenységekkel kapcsolatos kiadások nagysága között a mintámra vonatkoztatva.

Szerettem volna megtudni, hogy a hallgatókat milyen mértékű ráfordítási hajlandóság jellemzi, a fizikai aktivitással összefüggésbe hozható javakkal kapcsolatban. Azt feltételeztem, hogy általános tendencia az aktív sportfogyasztási kiadások alacsony szintje. A különböző típusú sportolási lehetőségekkel kapcsolatos fogyasztói döntés többnyire elutasító jellegű. A túrázás és a sportfelszerelések vásárlása mutatta a legmagasabb átlagot, a többi érték az „egyáltalán nem” és a „kismértékben” kategóriái között helyezkedett el, mely egyértelművé tette, hogy az aktív sportfogyasztás iránti affinitás alacsony szinten van.

Végül azt is szerettem volna megtudni, hogy a hallgatók inkább a rövid távú befektetéseket részesítik-e előnyben, mint a hosszú távú befektetéseket. Azt feltételeztem, hogy inkább a rövid távú befektetések (napijegy) kerülnek előtérbe a válaszadók körében.

Ez a hipotézis nem igazolódott be, hiszen a vizsgálatból kiderült, hogy a bérletvásárlás és a napijegy vásárlásának alacsony szintje mellett nem a napijegy vásárlása a meghatározó. Sőt, az alacsonyabb jövedelemmel rendelkezők között szignifikánsan nagyobb bizonyos sporttevékenységek esetében a bérletet vásárlók aránya. Ennek a hátterében valószínűleg tudatos fogyasztói magatartás (megtakarítás) áll.

Hajdúböszörményben a szabadidősport lehetséges színterei közül az intézmény (kar) által biztosított sportolási lehetőségek a meghatározóak. A magánvállalkozások szerepe mérsékelt. Ez egyrészt a fizetőképes kereslet nagyságával, másrészt a szolgáltatások minőségével függ össze. A debreceni sportszolgáltatókkal csak kevesen tudnak 
versenyezni. Az informális szektor szerepe szintén mérsékelt, melyben a fö tényezőt az alacsony motiváltság és mozgásszegény életmód jelenti. A civil szervezetek pedig gyenge szálakkal kapcsolódnak az egyetemhez, melynek legfőb oka, hogy a szervezetek elsősorban a helyi fiatal és felnőtt lakosságot célozzák meg szolgáltatásaikkal, és egész évben elérhetőek. Az egyetemisták közül sokan járnak más településről (Debrecen) naponta, és a vizsgaidőszakok, valamint a nyári szünet is holtidő a szolgáltató szempontjából.

A település adottságait megvizsgálva megállapítható, hogy nincs egységes rendszere a helyi sportszolgáltatásoknak. A szerényebb kínálat miatt indokolt lenne a szolgáltatók közti kapcsolati hálózat kiépítése, egységes hallgatói kedvezményi rendszer kidolgozása és bevezetése (hosszútávú befektetések elősegítése), kari ösztönzők beépítése (szabadon választható tárgyak rendszerének bővítése). Ezek elsősorban a nappali tagozatos hallgatók esetében indukálhatnának rövidtávon is eredményeket.

Mivel a jövedelem és a szabadidő mennyisége szintén elkülöníti a levelezős és nappalis hallgatókat, így a javaslatok is két irányba mutatnak. A nappali tagozatos diákok számára a tantervi testnevelésen túl a tanórán kívüli (ingyenes) egyetemi sportolási lehetőségek bővítése (minőségi és mennyiségi szempontból egyaránt) lehet célravezető. A levelező tagozatos hallgatók számára pedig a sportszolgáltatók rugalmasabb ár- és időbeosztása hozhat változást (esti, hétvégi nyitvatartás).

A Gyermeknevelési és Gyógypedagógiai Kar gazdaságföldrajzi környezetének jellemzői (Debrecen elszívó ereje, a hajdúböszörményi sportszolgáltatások alacsonyabb színvonala a minőség- és a mennyiségmutatók alapján) miatt, illetve a hallgatók átlagos szociodemográfiai, szociokulturális és szocioökológiai jellemzői egyaránt előnytelen kiindulási helyzetet teremtenek a fizikai aktivitás növelése szempontjából karunkon.

\section{Köszönetnyilvánítás}

A publikáció elkészítését az EFOP-3.6.2-16-2017-00003 számú projekt támogatta. A projekt az Európai Unió támogatásával, az Európai Szociális Alap társfinanszírozásával valósult meg. 


\section{Hivatkozott források}

[1.] Ács P. - Hécz R. - Paár D. - Stocker M. (2011): A fittség (m)értéke - A fizikai inaktivitás nemzetgazdasági terhei Magyarországon. Közgazdasági Szemle, 58. évf., 7-8. sz., 689-708. o.

[2.] Ács P. (szerk.) (2015): Sport és Gazdaság. Pécs, Pécsi Tudományegyetem Egészségtudományi Kar. 593 o.

[3.] Bácsné Bába, É. - Fenyves,V. - Szabados, Gy. - Pető, K. - Bács, Z. - Dajnoki, K. (2018a): Sport Involvement Analysis in Hungary, in the North Great Plain Region. Sustainability, Vol. 10. No. 5.

DOI: $\underline{10.3390 / \text { su10051629. }}$.

[4.] Bácsné Bába, É. - Pfau, C. - Dajnoki, K. - Müller, A. (2018b): Examining the quality parameters of sports services. In: Šimonek, J. - Dobay B. (szerk.) Sport science in motion: proceedings from the scientific conference. 236243. p.

[5.] Bácsné B. É. - Fenyves V. - Dajnoki K. - Szabados Gy. N. (2018c): Sportszolgáltatások kínálatának elemzése szervezeti szempontok alapján. International Journal of Engineering and Management Sciences / Müszaki és Menedzsment Tudományi Közlemények, 3. évf. 4. sz. DOI: 10.21791/IJEMS.2018.4.38.

[6.] Bácsné Bába É. - Balogh R. - Bács Z. - Fenyves V., Dajnoki K. (2018d): Sportszolgáltatások keresleti, kínálati oldalának elemzési lehetőségei. Studia Mundi - Economica, 5. évf. 3. sz. 19-33.

DOI: $10.18531 /$ Studia.Mundi.2018.05.03.19-33

[7.] Bácsné Bába É. - Balogh R. - Bács B. A. - Molnár A. - Fenyves V. - Müller A. (2019a): A passzív sportfogyasztás motivációinak vizsgálata nemek tükrében. Economica (Szolnok), 10. évf. 1. sz. 30-35. o.

[8.] Bácsné Bába É. - Fenyves V. - Szabados Gy. - Dajnoki K. - Müller A. Bács Z. (2019b): A sportágazat nemzetgazdasági jelentőségének vizsgálata beszámoló adatok alapján 2014-2016-os időszakban. Jelenkori Társadalmi és Gazdasági Folyamatok, 13. évf. 3-4. sz. 93-103. o.

[9.] Bujdosó, Z. - Dávid, L. (2013): Extreme sports and other activities in tourism with special regard to the Mátra Mountain. Journal of Physical Education and Sport, Vol. 13. No. 1.39-45. p.

[10.] Dajnoki, K.- Szabados, Gy.- Bácsné Bába, É. (2018): A Case Study on Human Resource Management Practice of a Sport Organization. International Journal of Engineering and Management Sciences / Müszaki és Menedzsment Tudományi Közlemények, Vol. 3. No. 4.

DOI: $10.21791 /$ IJEMS.2018.4.34.

[11.] Eurobarometer (2010, 2014): Sport and Phisical Activity. 
[12.] Fenyves V. - Dajnoki K. - Bácsné Bába É. (2019): Sportolási szokások vizsgálata a Campus Sportfesztivál tapasztalatai alapján. Acta Carolus Robertus, 9. évf. 2. sz. 27-40. o. DOI: 10.33032/acr.2019.9.2.27

[13.] Fritz P. - Schaub G-né. - Hegedűs I. (2007): Kapcsolat az életmód, szabadidő és rekreáció között. Magyar Sporttudományi Szemle, 28. évf. 2. sz. $52-$ 56. o

[14.] Gabnai Z. - Müller A. - Bács Z. - Bácsné Bába É. (2019): A fizikai inaktivitás nemzetgazdasági terhei. Egészségfejlesztés, 60. évf. 1. sz. 20-30. o.

[15.] Kovács K. (2015): A sport mint támogató faktor a felsőoktatásban. CHERD-H, Debrecen, 270 o.

[16.] Laczkó T. - Rétsági E. (2015): A sport társadalmi aspektusai. Pécs, Pécsi Tudományegyetem Egészségtudományi Kar. 227 o.

[17.] Laczkó T. - Melczer Cs. (2015): Az egészségsport alapjai. Pécs, Pécsi Tudományegyetem Egészségtudományi Kar. 200 o.

[18.] Madarász T. - Dajnoki K. - Fenyves V. - Bácsné Bába É. (2019): Sportolást befolyásoló tényezők feltárása a jövő munkavállalói generációja tekintetében - essettanulmány a DE-GTK hallgatói körében. In: Bácsné Bába É. - Müller A. (szerk.) „Mozgással az egészségért” A fizikai aktivitás jelentősége a jövő munkavállalóinak egészségmegőrzésében : Nemzetközi Konferencia és Workshop: Válogatott tanulmánykötet. Debrecen, Debreceni Egyetem, 66-74. o.

[19.] Paár D. (2013): A magyar háztartások sportfogyasztásának gazdasági szempontú elemzése. [PhD-disszertáció] Sopron: Nyugat-magyarországi Egyetem, Közgazdaságtudományi Kar, Széchenyi István Doktori Iskola, 175 o.

[20.] Pfau C. - Domonkos Sz. (2016a): Szabadidősport a felsőoktatásban. Taylor Gazdálkodás- és szervezéstudományi folyóirat, 8. évf. 2. sz. 111-117. o.

[21.] Pfau C. (2016b): Hallgatói szabadidősport szervezése és jellemzői a felsőoktatásban. Taylor Gazdálkodás- és szervezéstudományi folyóirat, 9. évf. 4. sz. 5-15. o.

[22.] Szabó A. (2015): Az egyetemisták és főiskolások Magyarországon, 2015. Szeged, Belvedere Meridionale, 43 o.

DOI: $10.14232 /$ belvbook.2015.58516 


\section{Szerző:}

\section{Szerdahelyi Zoltán}

PhD-hallgató

Ihrig Károly Gazdálkodás- és Szervezéstudományok Doktori Iskola

III. évfolyam, levelező tagozat

szerdahelyi.zoltan@ped.unideb.hu 